\title{
ANALISIS AKTIVITAS BELAJAR SISWA KELAS X PADA MATA PELAJARAN BIOLOGI DI SMA NEGERI 10 PALEMBANG
}

\author{
Gevina Intan Anggreiny ${ }^{1}$, Aseptianova ${ }^{2}$, Sulton Nawawi ${ }^{3}$ \\ Program Studi Pendidikan Biologi Fakultas Keguruan dan Ilmu Pendidikan \\ Universitas Muhammadiyah Palembang \\ Jalan Jenderal Ahmad Yani 13 Ulu Seberang Ulu II, Kec. Plaju, Kota Palembang, \\ Sumatera Selatan 30263 \\ Email: Anggreinydr@gmail.com ${ }^{1}$, Aseptianova@gmail.coml², sulton.bio@gmail.com ${ }^{3}$
}

Doi: https://doi.org/10.31943/mangiferaeduv4i2.55

Received: 04 Desember 2019 Accepted: 29 Januari 2020 Published: 31 Jauari 2020

Citasi: Author 1., Author 2., \& Author 3. 2019. Masukan titel (judul). Jurnal Mangifera

$E d u, 4(2), 157-166$

\begin{abstract}
Learning activities are activities carried out to produce changes in knowledge and skills in students. Learning activities contribute to the learning outcomes that students will get. The purpose of this study was to determine student learning activities in class $X$ virus material at SMA Negeri 10 Palembang. This research is a type of quantitative description research. The study population was all Grade X MIA students of SMA 10 Palembang. Class X MIA 2, MIA 4, MIA 5, and MIA 7 research samples were taken using a purposive sampling technique. Data obtained using observation sheets. The results of class X MIA 2 obtained a percentage of $67 \%$ including the excellent category, class X MIA 4 gained a percentage of $67 \%$ including the excellent category, class X MIA 5 gained a percentage of $65 \%$ including the excellent category and class X MIA 7 with a percentage of $62 \%$ including the excellent category. Student learning activities are categorized as useful because students follow learning by carrying out various learning activities. The conclusion is that the average learning activity of class $X$ students of SMA Negeri 10 Palembang on virus material obtains $65 \%$, including the excellent category. The highest percentage is emotional activity and mental activity, with a percentage of $71 \%$. The activity that gets the lowest percentage is drawing activity with a percentage of $48 \%$.
\end{abstract}

Keywords: Analysis, Learning Activities, Biology, Students.

\section{ABSTRAK}

Aktivitas belajar merupakan kegiatan yang dilakukan untuk menghasilkan perubahan pengetahuan dan keterampilan pada siswa. Aktivitas belajar berperan terhadap hasil belajar yang akan diperoleh siswa. Tujuan penelitian ini untuk mengetahui aktivitas belajar siswa pada materi virus kelas X SMA Negeri 10 Palembang. Penelitian ini merupakan jenis penelitian deskriptid kuantitatif. Populasi penelitian seluruh siswa Kelas X MIA SMA negeri 10 Palembang. Sampel penelitian kelas X MIA 2, MIA 4, MIA 5 dan MIA 7 yang diambil menggunakan teknik purposive sampling. Data diperoleh memnggunakan lembar observasi. Hasil penelitian kelas $X$ MIA 2 memperoleh persentase 67\% termasuk kategori baik, kelas X MIA 4 memperoleh persentase $67 \%$ termasuk kategori baik, kelas X MIA 5 memperoleh 
persentase $65 \%$ termasuk kategori baik dan kelas X MIA 7 dengan persentase $62 \%$ termasuk kategori baik. Aktivitas belajar siswa termasuk kategori baik dikarenakan siswa mengikuti pembelajaran dengan melaksanakan berbagai aktivitas dalam belajar. Kesimpulan yaitu rata-rata aktivitas belajar siswa kelas X SMA Negeri 10 Palembang pada materi virus memperoleh 65\% termasuk kategori baik. Persentase tertinggi yaitu aktivitas emosional dan aktivitas mental dengan persentase $71 \%$. Aktivitas yang memperoleh persentase terendah yaitu aktivitas menggambar dengan persentase $48 \%$.

Kata Kunci: Analisis, Aktivitas Belajar, Biologi, Siswa.

\section{PENDAHULUAN}

Pendidikan merupakan sebuah kegiatan yang dijalankan secara sengaja, teratur dan berencana dengan tujuan mengubah dan mengembangkan perilaku yang diinginkan agar menjadi individu yang memiliki kualitas (Ferry, 2015). Pendidikan pada abad 21 menuntut berbagai keterampilan yang harus dikuasai oleh siswa, sehingga diharapkan pendidikan dapat mempersiapkan siswa untuk menguasai berbagai keterampilan tersebut agar menjadi pribadi yang sukses dalam hidup. Salah satu yang ingin dicapai pada keterampilan pendidikan abad 21 yaitu mendesain aktivitas belajar yang relevan dengan dunia nyata. Kegiatan pembelajaran yang dibuat untuk menghubungkan antara pengalaman siswa dengan masalah dunia nyata, nanti akan mengubah fokus siswa dalam belajar. Apabila siswa menyadari keterkaitan antara yang mereka pelajari dengan dunia nyata adalah hal yang penting, maka motivasi mereka akan meningkat, begitu juga dengan belajarnya. Pengalaman siswa yang ada di sekolah mungkin sangat berbeda dari kehidupan mereka di luar sekolah. Penggunaan konteks dunia nyata adalah kunci dari pembelajaran pada pendidikan abad ke-21 (Zubaidah, 2016).

Aktivitas belajar merupakan kegiatan yang dilakukan untuk menghasilkan perubahan pada pengetahuan, nilai-nilai sikap, dan keterampilan pada siswa sebagai latihan yang dilaksanakan secara sengaja dan sadar untuk memperoleh hasil belajar (Rosiana \& Margiati, 2012). Aktivitas belajar berperan penting dalam menentukan hasil belajar yang baik pada siswa (Fatmawati, Santosa, \& Ariyanto, 2013). Hasil belajar yang baik merupakan tujuan dari siswa yang melakukan sebuah pendidikan melalui proses belajar. Aktivitas belajar yang baik merupakan kondisi ketika siswa aktif dalam mengolah dan merespon informasi yang disampaikan oleh guru. Siswa yang aktif di dalam kelas dapat dilihat ketika anak tersebut melakukan aktivitas belajar seperti mendengarkan pendapat 
orang lain, berdiskusi, mengerjakan laporan tugas, membantu teman yang kesulitan dan lain-lain (Susanto, 2016).

Berdasarkan wawancara dengan salah satu guru pengampu mata pelajaran Biologi di SMA Negeri 10 Palembang penelitian mengenai aktivitas belajar siswa pada mata pelajaran Biologi di SMA Negeri 10 Palembang pernah dilakukan di sekolah tersebut pada tahun 2014 oleh guru. Penelitian aktivitas belajar saat itu guru hanya mengukur 4 indikator aktivitas belajar yaitu aktivitas memperhatikan, aktivitas lisan, aktivitas motorik, dan aktivitas menulis. Hasil yang diperoleh pada penelitian tersebut menjelaskan bahwa masih ada beberapa aktivitas belajar siswa yang belum optimal. Aktivitas memperhatikan yang memperoleh 54\% dengan kriteria kurang, aktivitas lisan memperoleh $46 \%$ dengan kriteria kurang, aktivitas motorik memperoleh $62 \%$ dengan kriteria tinggi dan aktivitas menulis memperoleh $50 \%$ dengan kriteria kurang.

Aktivitas belajar adalah segala kegiatan yang dirancang oleh guru untuk memfasilitasi kegiatan belajar agar bisa terlaksana dengan baik seperti kegiatan diskusi, demonstrasi, simulasi, melakukan percobaan, dan lain-lain (Sanjaya, 2017). Aktivitas belajar merupakan kegiatan yang dilakukan untuk menghasilkan sebuah perubahan pengetahuan, nilai-nilai sikap, dan keterampilan pada siswa sebagai latihan yang dilaksanakan secara sengaja oleh siswa sendiri (Rosiana \& Margiati, 2012). Paul B. Diedrich (Sardiman, 2011) menyatakan aktivitas belajar siswa terdapat 8 indikator yang bisa dilihat dan diamati. Indikator yang bisa diukur pada aktivitas belajar siswa yaitu aktivitas memperhatikan (visual activities), aktivitas lisan (oral activities), aktivitas mendengarkan (listening activities), aktivitas menulis (writing activities), aktivitas menggambar (drawing activities), aktivitas emosional (emotional activities), aktivitas motorik (motor activities), dan aktivitas mental (mental activities).

Berdasarkan hasil analis kebutuhan awal melalui observasi \& wawancara, aktivitas belajar siswa di SMA Negeri 10 Palembang terlihat ada beberapa aktivitas belajar yang terlaksana dan ada beberapa aktivitas belajar yang tidak terlaksana. Begitu pula dengan respon siswa, ada sebagian siswa yang terlihat antusias dan ada sebagian siswa juga yang terlihat biasa saja ketika ingin memulai pembelajaran. Keadaan di dalam ruang kelas $\mathrm{X}$ SMA Negeri 10 Palembang ada beberapa siswa yang tidak melakukan aktivitas belajar. Ada sebagian siswa juga tidak memperhatikan penjelasan guru terutama siswa yang duduk di bangku belakang. Akhirnya kejadian ini akan membuat siswa tidak memahami materi yang disampaikan oleh guru dan siswa tidak melaksanakan aktivitas belajar yang seharusnya mereka lakukan. Siswa juga cenderung pasif pada saat guru memberikan waktu 
kepada siswa untuk menanyakan bagian materi Biologi yang belum dimengerti. Keadaan ini dapat dilihat pada saat proses pembelajaran berlangsung.

Hasil wawancara dengan beberapa siswa kelas X di SMA Negeri 10 Palembang menjelaskan bahwa kebanyakan siswa tidak begitu paham mengenai aktivitas belajar. Siswa tidak mengerti aktivitas belajar secara khusus itu merupakan aktivitas seperti apa. Keadaan seperti ini diketahui dari lembar wawancara yang telah di isi oleh siswa. Ada beberapa siswa mengetahui beberapa jenis aktivitas belajar. Berdasarkan uraian latar belakang di atas, tujuan penelitian ini untuk mengetahui aktivitas belajar siswa pada materi virus kelas X SMA Negeri 10 Palembang. Manfaat penelitian ini bermanfaat untuk mengetahui gambaran aktivitas belajar siswa pada materi virus dan melihat adakah perbedaan pada penelitian sebelumnya tentang aktivitas belajar siswa, serta bagi siswa sebagai bahan masukan untuk memperbaiki diri dalam meningkatkan aktivitas belajar dan meningkatkan prestasi belajar, selain itu dapat mengukur hasil belajar yang akan diperoleh jika aktivitas belajar terlaksana dengan baik.

\section{METODOLOGI PENELITIAN}

Jenis penelitian yang digunakan dalam penelitian ini yaitu deskriptif kuantitatif. Penggunaan metode deskriptif kuantitatif yaitu untuk mengukur persentase yang ada di dalam aktivitas belajar siswa kelas X SMA Negeri 10 Palembang. Persentase aktivitas belajar yang di ukur berupa aktivitas memperhatikan, aktivitas lisan, aktivitas mendengarkan, aktivitas menulis, aktivitas menggambar, aktivitas emosional, aktivitas motorik, dan aktivitas mental. Populasi dalam penelitian ini seluruh siswa kelas X MIA SMA Negeri 10 Palembang dengan sampel kelas X MIA 2, kelas X MIA 4, kelas X MIA 5 dan kelas X MIA 7.

Instrumen yang digunakan dalam penelitian ini yaitu lembar wawancara dan lembar observasi. Lembar wawancara yang digunakan berupa pertanyaan-pertanyaan tentang aktivitas belajar siswa. Lembar wawancara digunakan untuk memperoleh data awal dengan menggunakan 20 pertanyaan untuk guru dan 21 pertanyaan untuk siswa.

Lembar observasi aktivitas belajar siswa digunakan dalam penelitian ini diadaptasi dari lembar observasi yang dibuat oleh Laksmi (2011) dengan modifikasi seperlunya. Lembar observasi yang digunakan dalam bentuk skala penilaian dengan beberapa aspek yang diamati. Lembar observasi aktivitas siswa terdiri dari delapan indikator yaitu aktivitas memperhatikan, aktivitas lisan, aktivitas mendengarkan, aktivitas menulis, aktivitas menggambar, aktivitas emosional, aktivitas motorik, dan aktivitas mental. Lembar 
observasi aktivitas belajar siswa sebelum dipakai di lapangan terlebih dahulu dilakukan validasi ahli (expert judgment), hasilnya lembar observasi aktivitas belajar siswa dinyatakan valid.

Data aktivitas belajar siswa diperoleh dengan melakukan pengamatan selama kegiatan pembelajaran berlangsung. Pengamatan dilakukan oleh dua orang observer yang merupakan mahasiswa pendidikan Biologi. Siswa yang diamati sebanyak empat kelas yang telah dipilih dan ditetapkan sebelum pembelajaran dilaksanakan. Pengamatan dilakukan dengan memberikan nomor kepada siswa untuk mempermudah observer mengamati setiap siswa. Pertemuan pada penelitian ini dilakukan sebanyak dua kali. Observer menuliskan skor kategori yang muncul dengan memberi tanda cek $(\sqrt{ })$ pada baris dan kolom sesuai dengan setiap aspek yang dinilai.

Teknik analisis data dalam penelitian ini dianalisis dengan rumus (Laksmi, 2011).

$$
\text { Persentase }(\mathrm{P})=\frac{\text { jumlah skor yang diperoleh }}{\text { skor maksimum }} \times 100
$$

Hasil analisis data yang diperoleh selanjutnya akan dibandingkan dengan tabel kriteria penafsiran persentase untuk mengetahui kriteria aktivtas belajar siswa termasuk dalam kategori apa. Tabel kriteria penafsiran persentase adalah sebagai berikut:

\begin{tabular}{|c|c|}
\hline Interval Skor (\%) & Kategori \\
\hline $81-100$ & Sangat Baik \\
\hline $61-80$ & Baik \\
\hline $41-60$ & Cukup \\
\hline $1-40$ & Kurang \\
\hline
\end{tabular}

Sumber: (Rosba, 2015)

\section{HASIL DAN PEMBAHASAN}

Aktivitas belajar siswa pada pertemuan pertama membahas materi virus mulai dari sejarah perkembangan virus, pengertian virus, ciri-ciri virus, dan bentuk virus. Pertemuan kedua membahas replikasi virus dan peranan virus. Hasil rata-rata aktivitas belajar siswa kelas X SMA Negeri 10 Palembang yaitu 65,37 \%. Untuk lebih jelasnya terdapat pada Tabel 2. 
Tabel 2. Rata-rata Aktivitas Belajar Siswa Kelas X SMA Negeri 10 Palembang melalui Lembar Observasi

\begin{tabular}{ccc}
\hline Indikator & Rata-rata Aktivitas Belajar Siswa (\%) & Kriteria \\
\hline Aktivitas Memperhatikan & 67 & Baik \\
Aktivitas Lisan & 63 & Baik \\
Aktivitas Mendengarkan & 70 & Baik \\
Aktivitas Emosional & 71 & Baik \\
Aktivitas Mental & 71 & Baik \\
Aktivitas Menulis & 68 & Baik \\
Aktivitas Motorik & 65 & Baik \\
Aktivitas Menggambar & 48 & Cukup \\
Total & $\mathbf{6 5 , 3 7}$ & Baik \\
\hline
\end{tabular}

Aktivitas memperhatikan memperoleh kategori baik disebabkan karena siswa terlihat memperhatikan guru yang ada di depan kelas. Beberapa siswa juga mengikuti pembelajaran dengan baik dengan cara memperhatikan penjelasan guru dan memperhatikan apa yang telah disampaikan oleh temannya. Kegiatan memperhatikan perlu dilakukan siswa dikarenakan siswa dapat memahami materi yang telah disampaikan oleh guru. Apablia siswa memahami materi yang telah disampaikan dan dipelajari, maka akan berpengaruh terdahap hasil belajarnya. Oleh karena itu, perlu adanya kerjasama antara guru dengan siswa, dan siswa dengan siswa dalam proses pembelajaran (Hasmiati., dkk, 2017). Hal ini sesuai dengan yang dikemukakan oleh Jang, dkk. (2010), bahwa guru harus menciptakan suasana belajar yang mendukung keterlibatan siswa dalam proses pembelajaran.

Sejalan dengan penelitian Mufidah, Effendi \& Purwanti (2013) persentase aktivitas memperhatikan memperoleh kriteria tinggi dikarenakan siswa telah memperhatikan penjelasan guru saat guru menjelaskan, siswa mengerjakan latihan dari guru dengan baik, siswa tidak ada yang sibuk berbicara sendiri dengan temannya, tidak ada siswa yang bermain handphone dan makan di dalam kelas di saat jam belajar, tidak ada yang sibuk mengerjakan tugas mata pelajaran lain saat jam pembelajaran Biologi.

Aktivitas lisan memperoleh kategori baik. Kenyataan ini disebabkan oleh berbagai faktor seperti faktor internal yaitu dari dalam diri siswa itu sendiri seperti psikologis siswa. Menurut Mulyani (2013) faktor internal yang mempengaruhi aktivitas belajar yaitu faktor psikologis (kesiapan belajar). Psikologis siswa disini seperti kesiapan dari siswa yaitu ketika siswa memahami materi pembelajaran siswa akan mengerti apa yang ditanyakan oleh guru. Apabila ada hal yang kurang dimengerti oleh siswa maka siswa akan langsung menanyakannya kepada guru. 
Aktivitas mendengarkan termasuk kategori baik, dikarenakan kebanyakan siswa mendengarkan materi yang disampaikan oleh guru dan pendapat yang telah disampaikan oleh beberapa siswa lainnya. Aktivitas mendengar diukur selama pembelajaran langsung di kelas melalui lembar observasi. Selama proses pembelajaran guru lebih banyak berperan menjelaskan materi pembelajaran. Akibatnya aktivitas mendengarkan memperoleh persentase yang tinggi. Guru yang lebih banyak menjelaskan membuat kebanyakan siswa mendengarkan apa yang disampaikan oleh guru saat proses pembelajaran berlangsung. Menurut Rahmadani dan Anugraheni (2017) metode mengajar guru mampu meningkatkan aktivitas belajar siswa. Kenyataan ini terbukti pada aktivitas mendengarkan akan nampak setelah guru menjelaskan materi pembelajaran dan siswa akan mendengarkan penjelasan guru.

Aktivitas emosional termasuk kategori baik dipengaruhi oleh faktor aktivitas belajar seperti salah satu faktor eksternal yaitu cara guru mengajar. Guru yang menyampaikan dan memotivasi siswa dengan benar maka siswa akan antusias menunggu mulainya pembelajaran. Selain itu juga dipengaruhi oleh faktor internal yaitu psikologis dari siswa seperti kesiapan siswa. Semangat yang tinggi dan rasa antusias yang tinggi yang terlihat membuat aktivitas emosional memperoleh persentase yang tinggi.

Aktivitas mental termasuk kategori baik disebabkan karena ada beberapa siswa yang ada di kelas tersebut sudah berani menanggapi pendapat selama proses pembelajaran berlangsung. Selain itu juga dipengaruhi oleh faktor internal dari aktivitas belajar. Faktor internal berupa psikologis siswa yaitu intelegensi siswa mempengaruhi aktivitas mental. Menurut Supiana, Uliyanti dan Buwono (2013) aktivitas mental siswa ada beberapa hal yang dilakukan siswa yaitu siswa dapat menyimak penjelasan guru, siswa dapat mendiskusikan jawaban dari pertanyaan yang diberikan, bekerjasama dengan teman, bertanya tentang materi yang belum dimengerti menanggapi hasil pekerjaan temannya yang dapat menjawab pertanyaan, segera merespon pertanyaan yang muncul dan menyimpulkan materi ajar.

Aktivitas menulis termasuk kategori baik dikarenakan siswa telah dibiasakan guru dalam mencatat materi pembelajaran. Setiap materi yang telah dijelaskan dan dibahas bersama-sama akan dicatat oleh siswa pada buku catatan mereka yang nantinya catatan tersebut akan dinilai oleh guru yang mengajar. Menurut Hoirina, Afifah dan Dahlia (2015) kegiatan menulis membelajarkan siswa untuk menggunakan otak dan indera bekerja secara bersama-sama. Hal ini bisa diketahui ketika siswa menulis dan pada saat siswa menulis 
otaknya akan bekerja untuk menggagas suatu ide atau pikiran sementara jari-jari tangannya akan menuliskan ide.

Aktivitas motorik yang diukur yaitu aktivitas siswa dalam memperbaiki keterangan gambar yang diperintahkan guru dalam materi virus. Pada pertemuan pertama siswa diminta memperbaiki gambar struktur tubuh virus dengan susunan yang sengaja dibuat salah untuk dibenarkan. Pada pertemuan kedua siswa diminta memperbaiki siklus reproduksi virus yang terdiri dari siklus litik dan siklus lisogenik. Aktivitas motorik termasuk kategori baik dikarenakan sebagian siswa sudah mengetahui bagian-bagian dari struktur tubuh virus yang sebenarnya walaupun susunannya sudah diacak oleh guru. Namun, ada juga siswa yang masih salah mengisi dan membenarkan struktur tubuh virus dikarenakan siswa tidak mengetahui susunan yang sebenarnya. Akan tetapi lebih banyak siswa yang telah mengetahuinya terlebih dahulu. Kenyataan itu membuat persentase aktvitas motorik termasuk kriteria tinggi. Kenyataan ini juga bisa disebabkan oleh siswa terlebih dahulu melakukan aktivitas menggambar. Menurut Astuti dan Sutarni (2016) aktivitas belajar tinggi cenderung memiliki ciri dominan yaitu terlihat serius saat mengerjakan sesuatu yang diberikan oleh guru. Siswa yang memiliki aktivitas belajar sedang terlihat serius dalam mengerjakan sesuatu, namun terkadang masih kurang fokus selama mengerjakannya.

Chamany $(2008,17)$ juga mengungkapkan bahwa pembelajaran yang baik mampu menyajikan konsep-konsep yang dipelajari menjadi contoh yang nyata tentang keadaan atau fenomena pada lingkungan sekitar. Dengan belajar sambil bekerja (motorik) siswa dapat memperoleh pengetahuan, pemahaman, dan aspek tingkah laku lainnya, serta mengembangkan keterampilan yang bermakna untuk hidup di masyarakat.

Aktivitas menggambar termasuk kriteria cukup dikarenakan pada saat observasi pembelajaran di kelas berlangsung aktivitas menggambar jarang dilakukan selama proses pembelajaran. Guru juga jarang membiasakan aktivitas menggambar ini kepada siswa. Bagi siswa yang memiliki kemampuan dan suka menggambar maka akan memperoleh persentase tinggi apabila siswa mengetahui gambarnya. Namun, pada penilaian kali ini siswa tidak diberikan contoh gambar untuk digambar. Menurut Hoirina, Afifah dan Dahlia (2015) aktivitas menggambar akan baik apabila dapat menggambar gambar yang sama jika dilihat dengan gambar yang sebenarnya, gambar yang sederhana, tidak rumit dan mudah dipahami. 


\section{SIMPULAN}

Berdasarkan penelitian dan analisis data yang telah dilakukan aktivitas belajar terdiri dari delapan indikator yaitu aktivitas memperhatikan, aktivitas lisan, aktivitas mendengarkan, aktivitas emosional, aktivitas mental, aktivitas menulis, aktivitas motorik dan aktivitas menggambar. Rata-rata aktivitas belajar siswa kelas X SMA Negeri 10 Palembang pada materi virus memperoleh 65,37 \% termasuk kategori baik. Persentase tertinggi yaitu aktivitas emosional dan aktivitas mental dengan persentase $71 \%$. Aktivitas yang memperoleh persentase terendah yaitu aktivitas menggambar dengan persentase $48 \%$.

\section{DAFTAR PUSTAKA}

Astuti, E. D., \& Sutarni, S. (2016). Pengaruh Pembelajaran Role Play dan Guided Discovery terhadap Hasil Belajar Matematika ditinjau dari Aktivitas Belajar Siswa. Jurnal Pendidikan Matematika dan IPA, 2 (2), 1-7.

Chamany, K., Allen, D., \& Tanner, K. (2008). Making biology learning relevant to students: integrating people, history, and context into college biology teaching. CBE-Life Sciences Education, 7(3), 267-278.

Fatmawati, D. N., Santosa, S., \& Ariyanto, J. (2013). Penerapan Strategi Pembelajaran Think Talk Write untuk Meningkatkan Aktivitas Belajar Biologi Siswa Kelas X-1 SMA Al Islam 1 Surakarta Tahun Ajaran 2009/2010. Jurnal Bio-Pedagogi, 2 (1), 115.

Ferry, D. (2015). Analisis Proses Pembelajaran Biologi Pada Materi Protista Kelas X SMA Negeri 5 Sungai Penuh. Jurnal Program Studi Biologi Program Pascasarjana Universitas Negeri Padang, 2 (2), 23-31.

Hasmiati, H., Jamilah, J., \& Mustami, M. K. (2017). Aktivitas dan Hasil Belajar Siswa Pada Pembelajaran Pertumbuhan dan Perkembangan Dengan Metode Praktikum. Jurnal Biotek, 5(1), 21-35.

Hoirina, Afifah, N., \& Dahlia. (2015). Analisis Aktivitas Belajar Biologi Siswa dengan menggunakan Media Gambar Kelas VII SMP Negeri 3 Rambah Samo Tahun Pembelajaran 2014/ 2015. e-Jurnal Mahasiswa Prodi Biologi, 1 (1), 1-4.

Jang, H., Reeve, J., \& Deci, E. L. (2010). Engaging students in learning activities: It is not autonomy support or structure but autonomy support and structure. Journal of educational psychology, 102(3), 588.

Laksmi, P. K. (2011). Penerapan Pendekatan Jelajah Alam Sekitar pada Materi Pengelolaan Lingkungan di SMP Negeri 10 Semarang. Skripsi. Tidak diterbitkan. Semarang: Fakultas Matematika dan Ilmu Pengetahuan Alam. Universitas Negeri Semarang. 
Mufidah, L., Effendi, D., \& Purwanti, T. T. (2013). Penerapan Model Pembelajaran Kooperatif Tipe Tps Untuk Meningkatkan Aktivitas Belajar Siswa Pada Pokok Bahasan Matrik. Jurnal Pendidikan Matematika STKIP PGRI Sidoarjo, 1 (1),117125.

Mulyani, D. (2013). Hubungan Kesiapan Belajar Siswa dengan Prestasi Belajar. Jurnal Ilmiah Konseling, 2 (1), 23-31.

Rahmadani, N., \& Anugraheni, I. (2017). Peningkatan Aktivitas Belajar Matematika Melalui Pendektan Problem Based Learning Bagi Siswa Kelas 4 SD. Jurnal Pendidikan dan Kebudayaan, 7 (3), 241-250.

Rosba, Evrialiani. (2015). Peningkatan Aktivitas dan Hasil Belajar Siswa menggunakan Model Pembelajaran Think Pair Share yang disertasi LKS pada Mata Pelajaran IPABiologi Kelas VIIA SMP Taman Siswa Padang. Jurnal BioCONCETTA, 1 (2), 2638 .

Rosiana, K. Y., \& Margiati, S. H. (2012). Peningkatan Aktivitas Belajar Siswa menggunakan Metode Inkuiri pada Pembelajaran Ilmu Pengetahuan Alam. Jurnal Pendidikan dan Pembelajaran, 1 (1), 1-10.

Sanjaya, W. (2017). Strategi dan Pembelajaran Berorientasi Standar Proses Pendidikan. Jakarta: Kencana.

Sardiman. (2011). Interaksi dan Motivasi Belajar Mengajar. Jakarta: Raja Grafindo.

Supiana, N., Uliyanti, E., \& Buwono, S. (2013). Peningkatan Aktivitas Belajar Siswa Dengan Menggunakan Media Visual Pada Pembelajaran IPA di Kelas IV SDN 47 Kubu Raya. Jurnal Pendidikan dan Pembelajaran, 2 (1), 1-16.

Susanto, H. P. (2016). Analisis Hubungan Kecemasan, Aktivitas, dan Motivasi Berprestasi dengan Hasil Belajar Matematika Siswa. Jurnal Tadris Matematika, 9 (2), 134-147.

Zubaidah, S. (2016). Keterampilan Abad ke-21: Keterampilan yang diajarkan melalui Pembelajaran.Artikel.(https://www.researchgate.net/publication/318013627_KETER AMPILAN_ABAD_KE21_KETERAMPILAN_YANG_DIAJARKAN_MELALUI_ PEMBELAJARAN. Diakses tanggal 15 April 2018. Hal. 1-17.) 